\title{
The first data on the population parameters and morphometry of Mesogobius batrachocephalus (Pallas 1814) (Family: Gobiidae) in the southern Black Sea
}

\author{
Mehmet AYDIND \\ Cite this article as: \\ Aydın, M. (2021). The first data on the population parameters and morphometry of Mesogobius batrachocephalus (Pallas 1814) (Family: Gobiidae) in the \\ southern Black Sea. Aquatic Research, 4(2), 116-128. https://doi.org/10.3153/AR21009
}

Ordu University, Fatsa Faculty of Marine Science, Ordu, Turkey

ORCID IDs of the author(s): M.A. 0000-0003-1163-6461

Submitted: 14.08 .2020

Revision requested: 18.09 .2020

Last revision received: 19.09 .2020

Accepted: 19.09.2020

Published online: 04.01.2021

Correspondence:

Mehmet AYDIN

E-mail: maydin69@hotmail.com

\begin{abstract}
Knout goby, Mesogobius batrachocephalus Pallas, 1814, which belongs to Gobiidae, inhabits in the Black Sea, Sea of Azov, the Caspian Sea and the rivers that flow in these three seas. The major population parameters and morphometry of Mesogobius batrachocephalus from the coasts of the southern Black Sea were investigated in this study. A total of 641 individuals were sampled between January 2019 and December 2019 between the depths of 2 to $120 \mathrm{~m}$ depth by using a trammel net with a mesh size of $17-24 \mathrm{~mm}$. The average length and weight values were calculated as $23.1 \mathrm{~cm}(5.3-34.0)$ and $130.1 \mathrm{~g}(1.34-377.54)$ respectively. The male to female ratio of the population was found as 1:0.91 ( $\mathrm{P}>0.05)$. Age of sampled 641 individuals varies between zero and seven. For all the sampled individuals, the von Bertalanffy growth parameters were calculated as; $\mathrm{L}_{\infty}=38.2 \mathrm{~cm}, \mathrm{k}=0.245$ year $^{-1}$ and $\mathrm{t}_{0}=-1.873$ year and the length-weight relationship was found as $\mathrm{W}=0.0058 \mathrm{TL}^{3.148}$. Total mortality $(0.481)$, natural mortality $(0.466)$, fishing mortality $(0.015)$, growth performance index (2.55) and condition factor (0.913) were calculated. The maximum value of gonadosomatic index was reached in March. Average relative fecundity was found to be 118.3 eggs per g (78.9-234.5), while the average diameter of the eggs was found as $2733.0 \mu \mathrm{m}$ \pm 221.18 (2287.1-3097.8). This study provides the first data on the population parameters and the morphometry of Mesogobius batrachocephalus. These data could contribute to the establishment of a sustainable management plan for fisheries resources in the Black Sea.
\end{abstract}

Keywords: Knout goby, Age, Growth, Reproductive, Fecundity, Morphometry, Black Sea

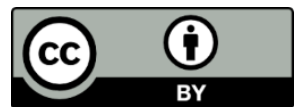

(C) 2021 The Author(s) 


\section{Introduction}

The knout goby (Gobiidae) family, Mesogobius batrachocephalus (Pallas 1814), inhabits in the Black Sea, Caspian Sea and temporarily inhabits marine waters (Freyhof, 2011; Pinchuk et al., 2004). Among this ecologically diverse species group, knout goby (Froese and Pauly, 2019), is a Black Sea endemic fish found on sandy or rocky bottoms of inshore habitats, estuaries and brackish/fresh water lagoons (Freyhof, 2011). There are 34 (17.99\%) endemic fish species in the Black Sea. Seventeen of 34 endemic fish species in the Black Sea belong to the Gobiidae (Yankova et al., 2014). The knout goby has a certain commercial value (Freyhof, 2011) as well as in Turkish coast of Black Sea (Pers. Obs. Dr. Mehmet AYDIN). There were some studies focusing on the lengthweight relationship of knout goby for the Turkish coasts of the Black Sea (Demirhan and Can, 2007; Ak et al., 2009; Çalık and Erdoğan-Sağlam, 2017; Bengil and Aydın, 2020) and some studies related to the feeding ecology of the knout goby of the Black Sea (Porumb, 1961; Bănărescu, 1964; Mihălcescu, 2005; Crețeanu and Papadopol, 2006; Roşca and Surugiu, 2010; Roşca and Mânzu, 2011; Bengil and Aydın , 2020).

This study aims to contribute to the limited knowledge on the knout goby morphometry and its population parameters inhabiting the southern Black Sea. The main population parameters (age, length and weight relationships, sexual composition, growth, condition factor, and gonadosomatic index and morphometry properties) of $M$. batrachocephalus from coasts of the southern Black Sea are determined in this study. This is the first attempt to study on M. batrachocephalus in the Ponto-Caspian region and certainly will provide a significant contribution to the current literature and very important in terms of observation of the population.

\section{Material and Methods}

Samples of knout goby were collected monthly (January 2019 - December 2019) between the depths of 2 to $120 \mathrm{~m}$ depth by using a trammel net with a mesh size of $17-24 \mathrm{~mm}$, which is commonly used by the fishermen of the southern coasts of the Black Sea $\left(41^{\circ} 08^{\prime} 41.93^{\prime \prime} \mathrm{N}-37^{\circ} 17^{\prime} 41.29^{\prime \prime} \mathrm{E}\right.$ and $40^{\circ} 57^{\prime} 55.68^{\prime \prime} \mathrm{N}-38^{\circ} 07^{\prime} 24.97^{\prime} \mathrm{E}$ ) (Figure 1). Samples were brought straight to the laboratory and morphological measurements were conducted while they are fresh. Total length measurements were performed by using a measuring board with a accuracy of $1 \mathrm{~mm}$, while the weight and gonad weight (GW) measurements were made on an electronic scale with a accuracy of $0.01 \mathrm{~g}$. Sex determinations were made through macroscopic observation of the gonad.

\section{Length and Weight Relationships (LWRs)}

LWRs of the species was estimated by applying the exponential regression model, $\mathrm{W}=\mathrm{aTL}^{\mathrm{b}}$, where $a$ and $b$ are regression constants (Ricker, 1975). LWR was analyzed separately for males and females. The regression co-efficient for isometric growth is " 3 ", while values greater or lesser than this value indicates an allometric growth. Regression analysis was used to estimate the confidence interval of " $b$ " value and statistical relationships of morphometric measurements.

\section{Age Determination}

Sagittal otoliths of each specimen collected in this study were used for age determination. Otoliths were prepared for age determination and placed into a black pit plate. Stereomicroscope (up to X10 magnification) was used with illumination from top and side.

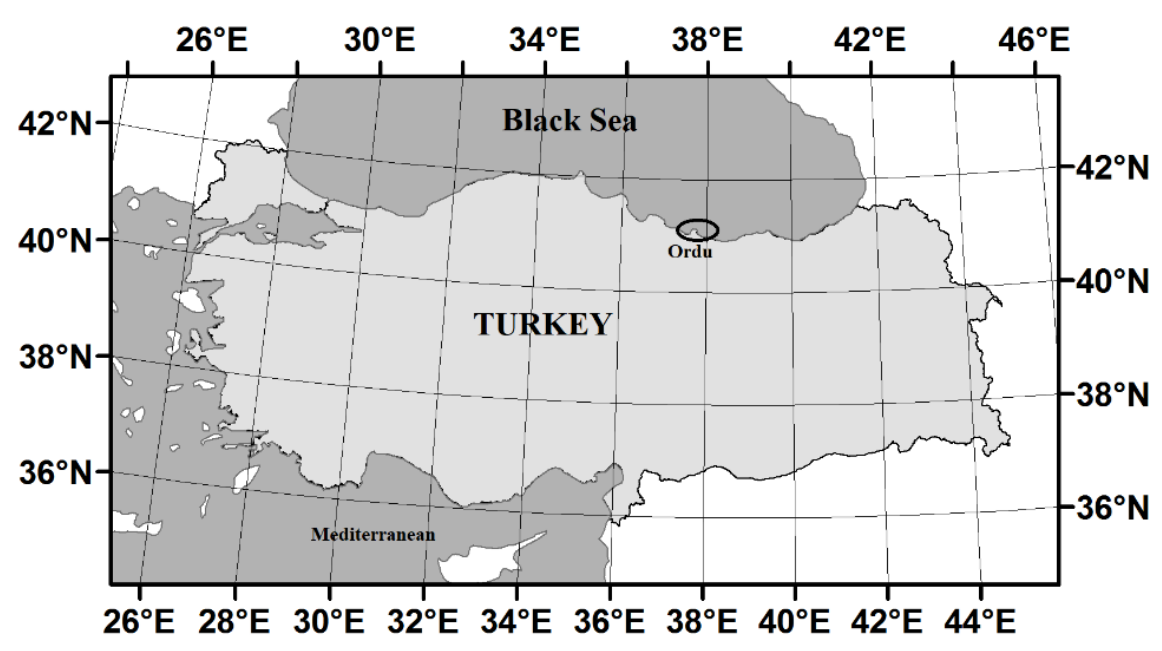

Figure 1. Study area 


\section{Growth Parameters}

The von Bertalanffy growth equation (VBGE) was used to describe the growth of $M$. batrachocephalus for the total number of individuals sampled (King, 1995; Sparre and Venema, 1992). $\mathrm{L}_{(\mathrm{t})}=\mathrm{L}_{\infty}\left(1-\mathrm{e}^{-\mathrm{k}(\mathrm{t}-\mathrm{t} 0)}\right)$, where $\mathrm{L}_{\mathrm{t}}$ is the total length at age $t, L_{\infty}$ is the asymptotic length, $k$ is the growth coefficient, and $t_{0}$ is the theoretical age when the fish was at zero total length. The same function was also used for describing the growth in weight; $\mathrm{W}_{(\mathrm{t})}=\mathrm{W}_{\infty}\left(1-\mathrm{e}^{-\mathrm{k}(\mathrm{t}-\mathrm{to})}\right)^{\mathrm{b}}$, where $\mathrm{W}_{\mathrm{t}}$ is the total weight, $\mathrm{W}_{\infty}$ is the asymptotic weight, and " $\mathrm{b}$ " is the power constant of the length-weight relationship. Values of $\mathrm{L}_{\infty}, \mathrm{t}_{0}$ and $\mathrm{K}$, which are parameters of the VBGE, were estimated by using the method of Ford-Walford (Gulland, 1969; Pauly, 1984). Growth parameters were estimated by using following formulas (King, 1995; Sparre and Venema, 1992): $\mathrm{L}_{\infty}=\mathrm{a} /(1-\mathrm{b}), \mathrm{k}=-\mathrm{Ln} \mathrm{b}, \mathrm{t}_{0}=\mathrm{t}+(1 / \mathrm{k}) * \mathrm{Ln}$ $\left[1-\left(\mathrm{L}_{\mathrm{t}} / \mathrm{L}_{\infty}\right)\right]$.

Munro's phi-prime growth performance $\left(\varnothing^{\prime}\right)$ was calculated by using the formula of Pauly and Munro (1984): $\varnothing^{\prime}=\log (\mathrm{k})+2 * \log \left(\mathrm{L}_{\infty}\right)$.

\section{Condition Factor}

Fulton's coefficient of condition factor (CF) of $M$. batrachocephalus was calculated monthly by the equation $\mathrm{CF}=\left(\mathrm{W} / \mathrm{TL}^{3}\right) \times 100($ Ricker, 1975).

Gonadosomatic Index. Monthly values of the gonadosomatic index (GSI) were calculated for each sex.

$\mathrm{GSI}=(\mathrm{GW} / \mathrm{W}) \times 100($ De Vlaming et al., 1982)

\section{Fecundity}

Eggs of female individuals were collected and counted in March, when GSI reached the maximum in spawning season. A total of 33 individuals were examined for this purpose. When the relevant individuals were caught, gonads were collected, and eggs in ovaries were counted, immediately. Subsamples were counted using the gravimetric method, and the total number of eggs were calculated according to the following formula (Holden and Raitt, 1974): $F=\frac{G}{g} \times n$, where; $F$ is the total number of eggs in the ovary, $G$ is ovary weight $(\mathrm{g}), \mathrm{g}$ is the weight of the subsample taken from the ovary (g), and " $\mathrm{n}$ " is the total number of eggs (including previtellogenic oocytes) in the ovary. It should be noted that only the mature oocytes (Lowerre-Barbieri et al., 2011) were taken into account while measuring the egg diameters.

\section{Mortality Rates}

Natural mortality (M) was computed by the equation (Pauly, 1980):

$\log M=-0.0066-0.2790 \log L_{\infty}+0.6543 \log k+0.4634$ $\log T$

Where $\mathrm{T}$ is the average water temperature $\left(15^{\circ} \mathrm{C}\right)$ of the southern Black Sea. Fishing mortality $(\mathrm{F})$ was estimated as $\mathrm{F}=\mathrm{Z}-\mathrm{M}$ by Beverton and Holt (1957), where Survival rate (S) can be computed from the equation: $S_{(t)}=e^{-Z(t)}$ (Ricker, $1975)$ and the total mortality rate $(Z)$ was calculated using the survival rate (S), as follows: $Z=-\ln (S)$ (Ricker, 1975; Gulland, 1969).

\section{Morphometry}

Ninety-four individuals were sub-sampled to determine the morphometric characteristics. Fourteen morphometric measurements of $M$. batrachocephalus were performed. These are: 1. Total length (TL), 2. Standard length (SL), 3. Head length (HL), 4. Post-orbital distance (POD), 5. Eye diameter (ED), 6. Pre-dorsal distance (PDD), 7. Length of D1 fin basis (D1L), 8. Length of D2 fin basis (D2L), 9. Pre-anal distance (PAD), 10. Length of anal fin basis (AL), 11. Max. body depth (MBD), 12. Caudal peduncle minimal depth (CPMD), 13. Pectoral length (PecL), 14. Pelvic length (PelL) (Figure 2). Digital caliper with $0.01 \mathrm{~cm}$ accuracy was used for morphometric measurements. Fourteen morphometric characters were evaluated as TL \%. Regression analysis of differences body parts against TL of the fish were drawn by least square method.

\section{Statistical Analysis}

The Pauly's t-test was used to compare the "b" values (Pauly, 1984) to determine whether there is any significant difference or not and chi-square test were used to compare sex in this study. Statistical applications were performed by using software of Microsoft Office Excel ${ }^{\circledR}$ and SPSS $18^{\circledR}$ package programme. 

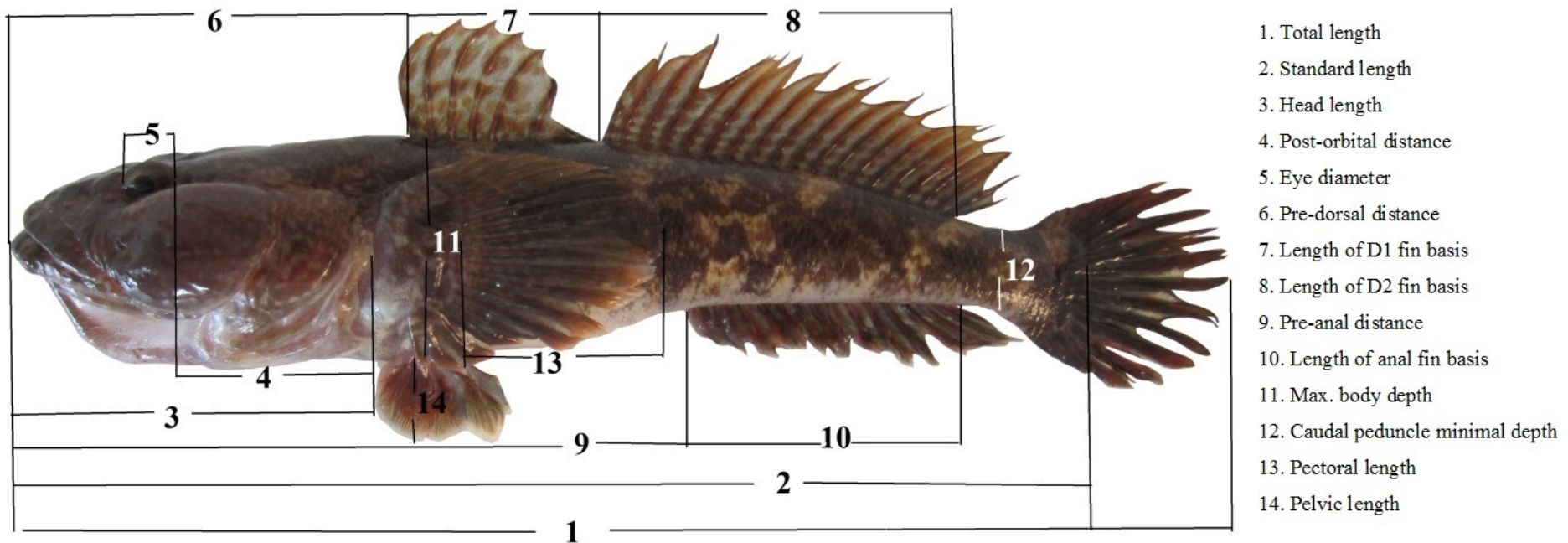

Figure 2. Overview of the morphometric measurements used in this study

\section{Results and Discussion}

\section{Length-Frequency Distribution}

A total of 641 individuals of knout goby species were obtained from the depths between 2 to $120 \mathrm{~m}$ during this study. The highest frequency belongs to $19-20 \mathrm{~cm}$ length group with 98 individuals $(15.3 \%)$. Minimum length was measured as $5.3 \mathrm{~cm}$, while the maximum individual was $34.0 \mathrm{~cm}$. Frequency distribution for each length group and the monthly variation of the length-frequency distribution are presented in Figure 3 and Figure 4, respectively.

\section{Sex Composition}

The percentage of total female and male individuals obtained during this study was calculated as $47.74 \%$ (306) and 52.26 $\%$ (335) respectively, which concludes a male to female ratio of 1:0.91. The difference between the sex was found to be statistically insignificant $\left(\chi^{2}=1.312, \mathrm{df}=1, \mathrm{P}>0.05\right)$.

\section{Length and Weight Relationship}

The length-weight relationship for all individuals and for separate sexes is shown in Figure 5. Statistical descriptions of length and weight were presented in Table 1. Results showed positive allometry $(b>3)$ for both clusters of the male, female and the total individuals $(\mathrm{P}>0.05)$ (Figure 5).

\section{Age Composition}

Sampled individuals have an age range of zero to seven. One year age group has presented with the highest frequency with a percentage of $39.0 \%$, while the percentage of the two oldest age group of 6 and 7 were found to be only 4 and 1 respectively (Table 2). Total number of the individuals in 0 age group was found to be 19 with a percentage of $2.96 \%$.

\section{Von Bertalanffy Growth Parameters}

Growth parameters of von Bertalanffy and equations were calculated and presented in Table 3. Growth performance value $\left(\varnothing^{\prime}\right)$ was estimated as 2.55 . Estimated and observed values of length age relationships were presented in Figure 6.

\section{Spawning Period}

The value of GSI in females started to increase by January and reached its peak value in March indicating that the spawning occurs in March. The average value of GSI for the female cluster is 20.96 in March, while the minimum value of GSI was found as 0.32 for September. Overall average value of GSI for female individuals was found as $4.70 \pm 6.32$. Overall pattern of the GSI variation displays a similar behavior for male and female clusters, while the GSI value for the male cluster is systematically lower than the female one (Figure 7).

\section{Fecundity}

A total of 33 female individuals were examined in March for fecundity. Size of the individuals varies between 18.0 $\mathrm{cm}$ and $32.7 \mathrm{~cm}$ in length, and $56.0 \mathrm{~g}$ and $372.9 \mathrm{~g}$ in weight. A mini-mum and maximum value of total number of the eggs was estimated as 1707.7 and 9209.5, respectively. Average fecun-dity was calculated as $4253.6 \pm 1563.53$. Relative fecundity was found to be 118.3 number/1g (48.9-234.5). Average di-ameter of eggs was measured as $2733.0 \mu \mathrm{m} \pm 221.18$ (2287.1-3097.8). 


\section{Condition Factor}

The average condition factor of $M$. batrachocephalus was calculated as $0.913 \pm 0.06(0.827-1.017)$ for all, 0.897 \pm 0.07 (0.778-0.994) for male and $0.928 \pm 0.07(0.850-1.061)$ for female (Figure 8).

\section{Mortality}

Mortality parameters are the most important indicators for the assessment of the decrease in stocks. Total mortality rate $(\mathrm{Z})$ was found as 0.481 , while the survival rate (S) was calculated as 0.618 . Natural mortality rate $(\mathrm{M})$ was calculated by using growth parameters of the species and average temperature at depth that species live. Assuming an average habitat depth of $30 \pm 15 \mathrm{~m}$ with an average sea temperature of $13^{\circ} \mathrm{C}$ for this species and utilizing the Pauly's approach $\mathrm{M}$ and $\mathrm{F}$ were estimated as 0.466 and 0.015 , respectively.

\section{Morphometric Characteristics}

Ninety-four individuals were sub-sampled to determine the morphometric characteristics of the species. The average length and weight of the sub-sampled group were calculated as $23.5 \mathrm{~cm}(9.1-33.4)$ and $127.78 \mathrm{~g}(5.91-337.76)$ respectively. The means, standard errors, minimum and maximum values of the morphometric characteristics of the subsampled group were given in Table 4. Also, the morphometric properties of the M. batrachocephalus were proportional to the total length and the smallest ratio was eye size $(3.7 \%)$ and the highest ratio was the standard size $(85.4 \%)$.

The relationships between the morphometric characteristics and the total length were analyzed with linear regression equations. Correlation coefficients for morphometric lengths-total length relationships were given in Table 5.

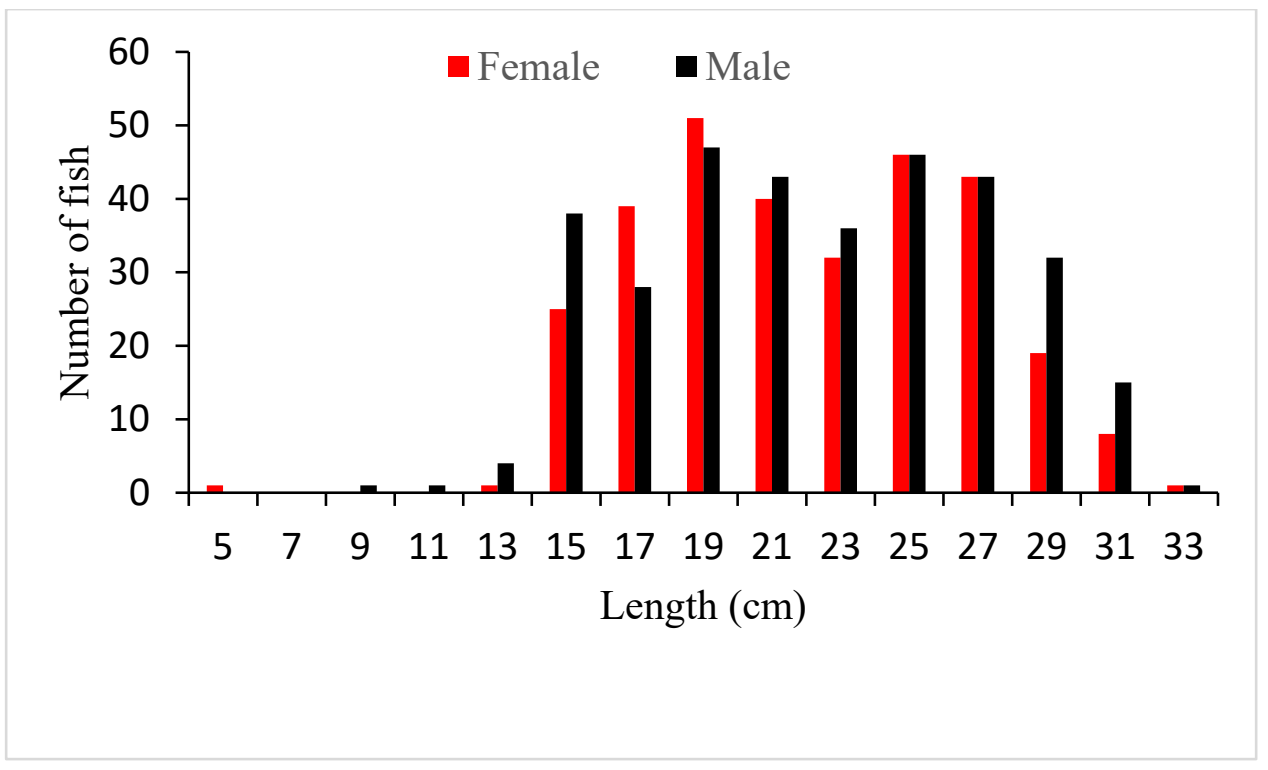

Figure 3. Frequency distribution of total length of Mesogobius batrachocephalus in the Black Sea 

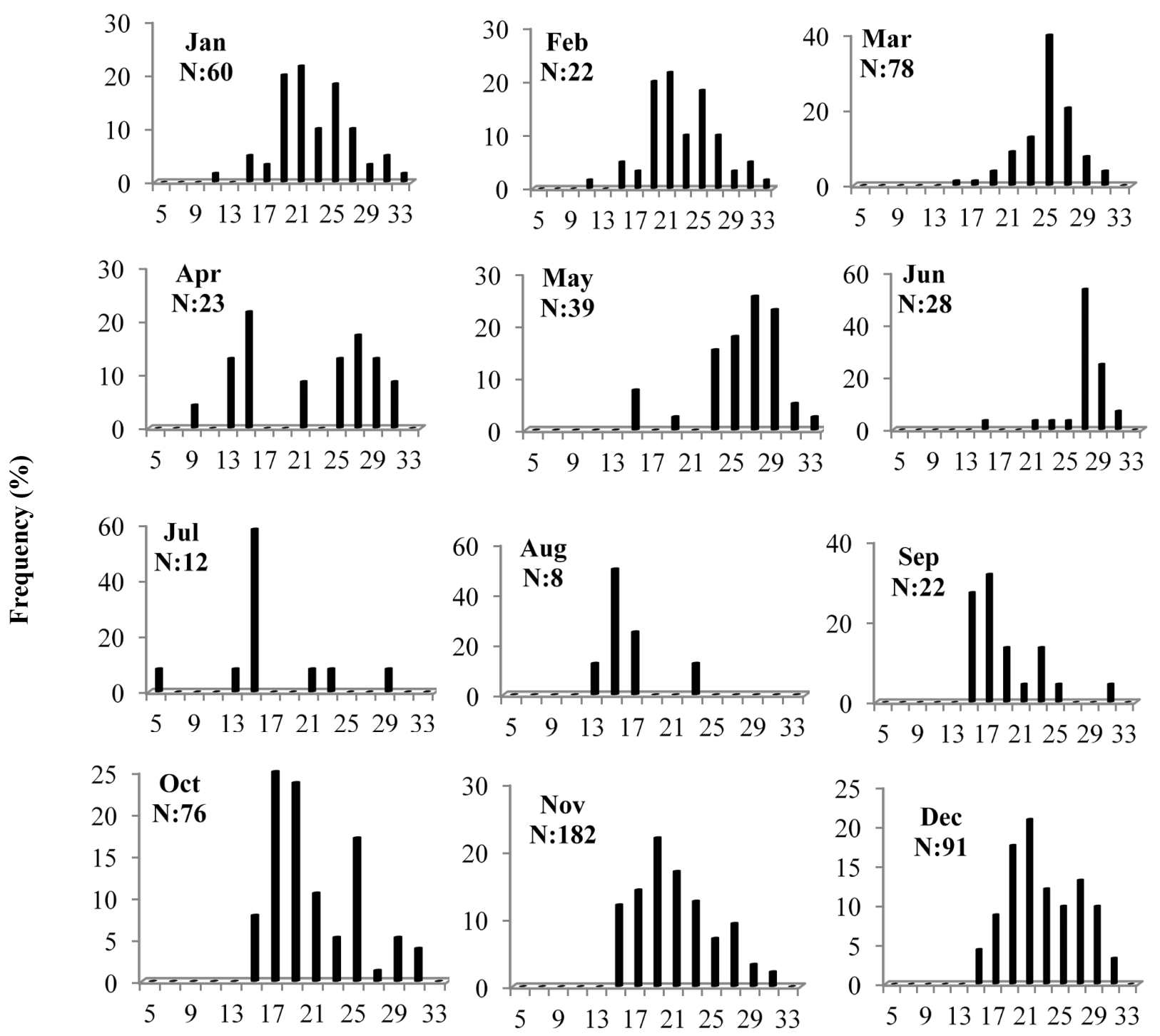

Total Length (cm)

Figure 4. Monthly total length- frequency distributions of Mesogobius batrachocephalus in the Black Sea 

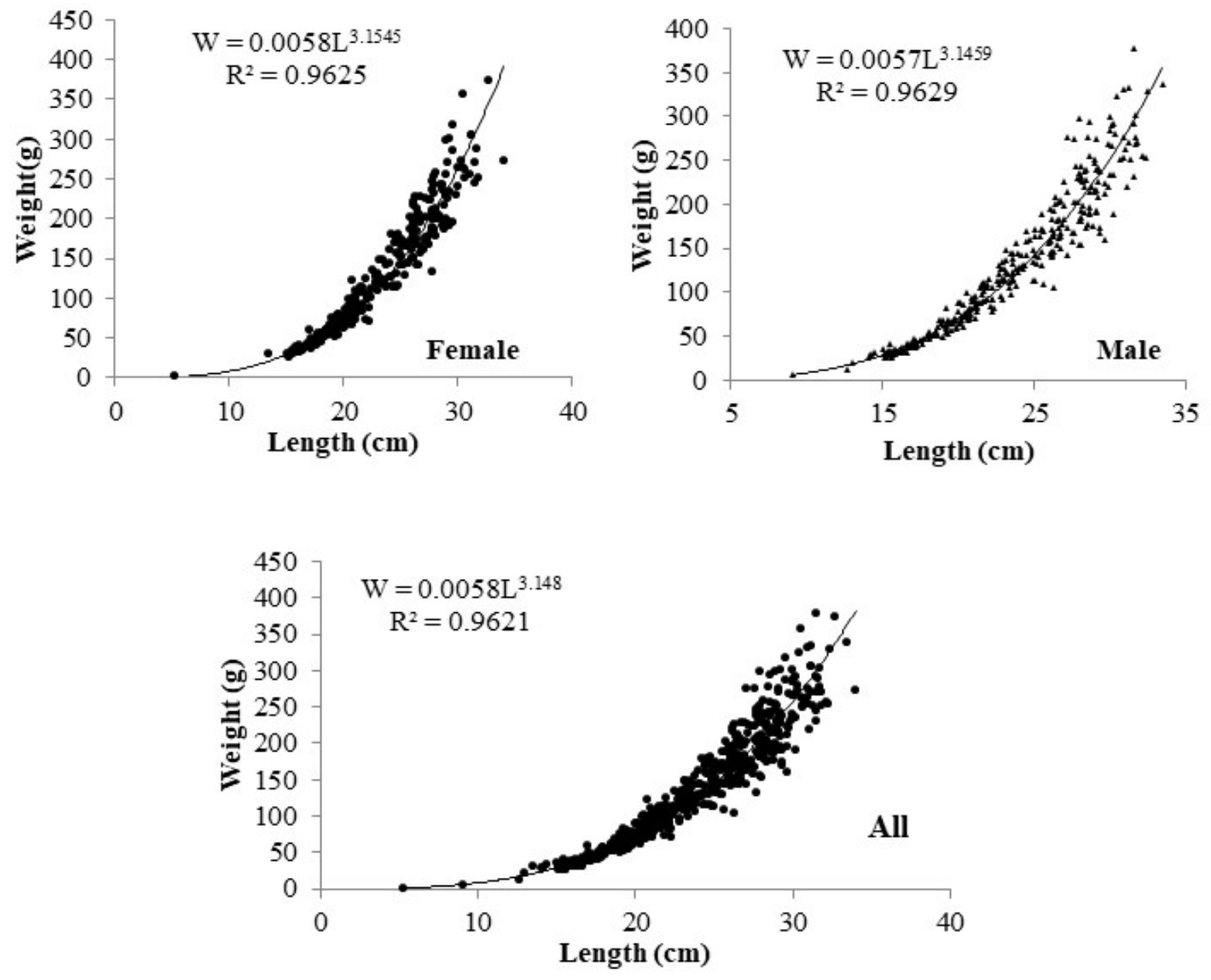

Figure 5. Total length-weight relationship of Mesogobius batrachocephalus in the Black Sea

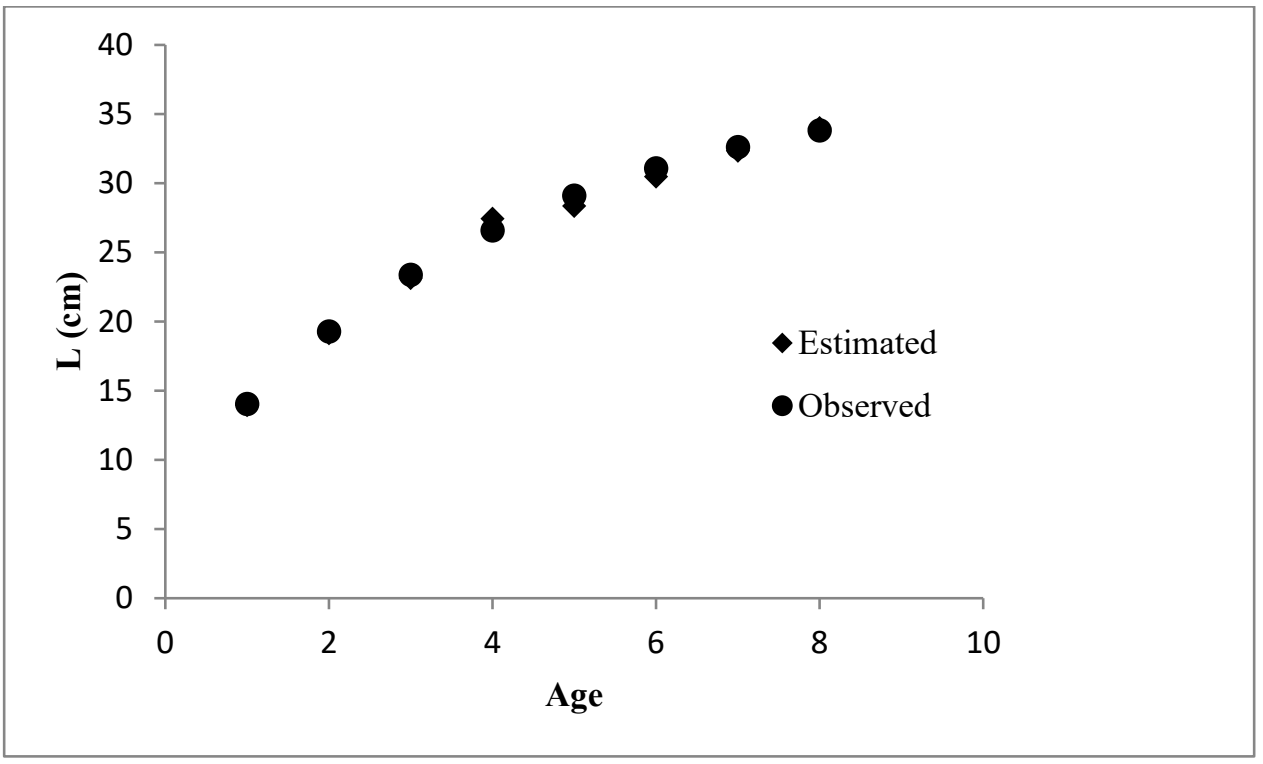

Figure 6. Age-total length relationship of Mesogobius batrachocephalus in the Black Sea 


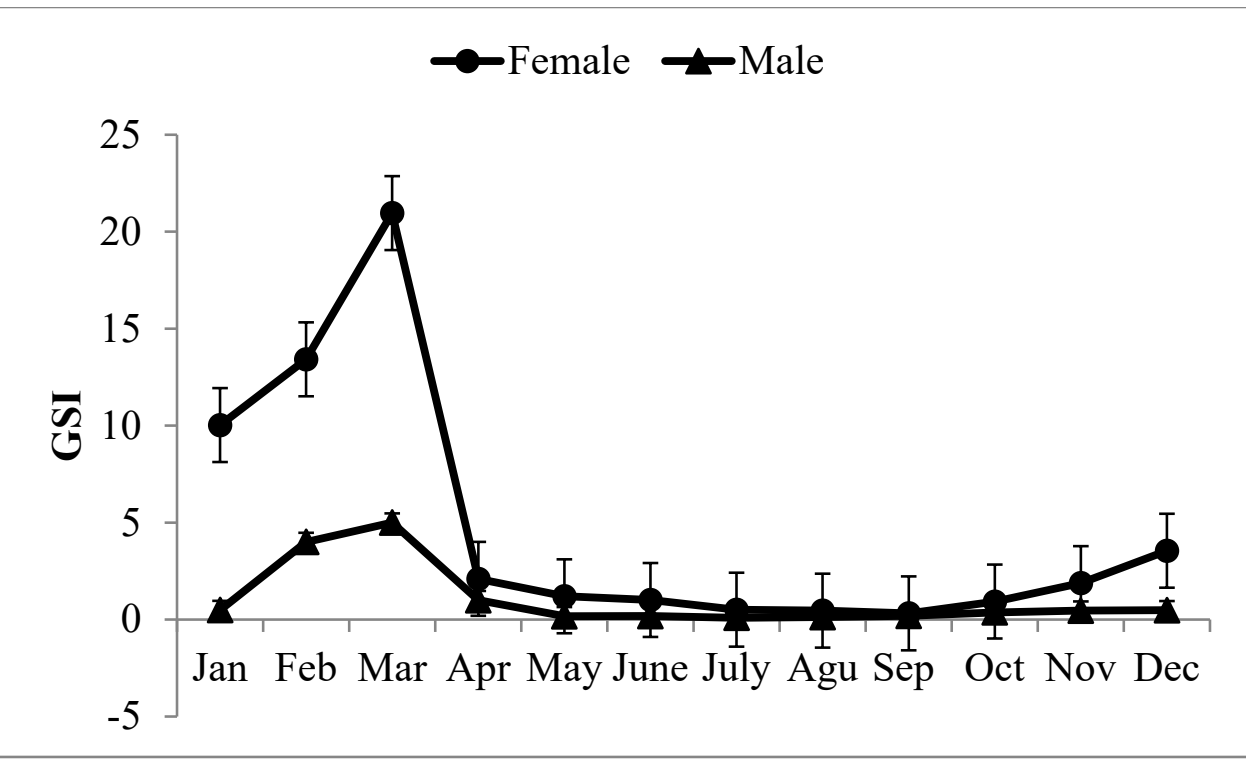

Figure 7. Monthly distribution of gonadosomatic index (GSI) values

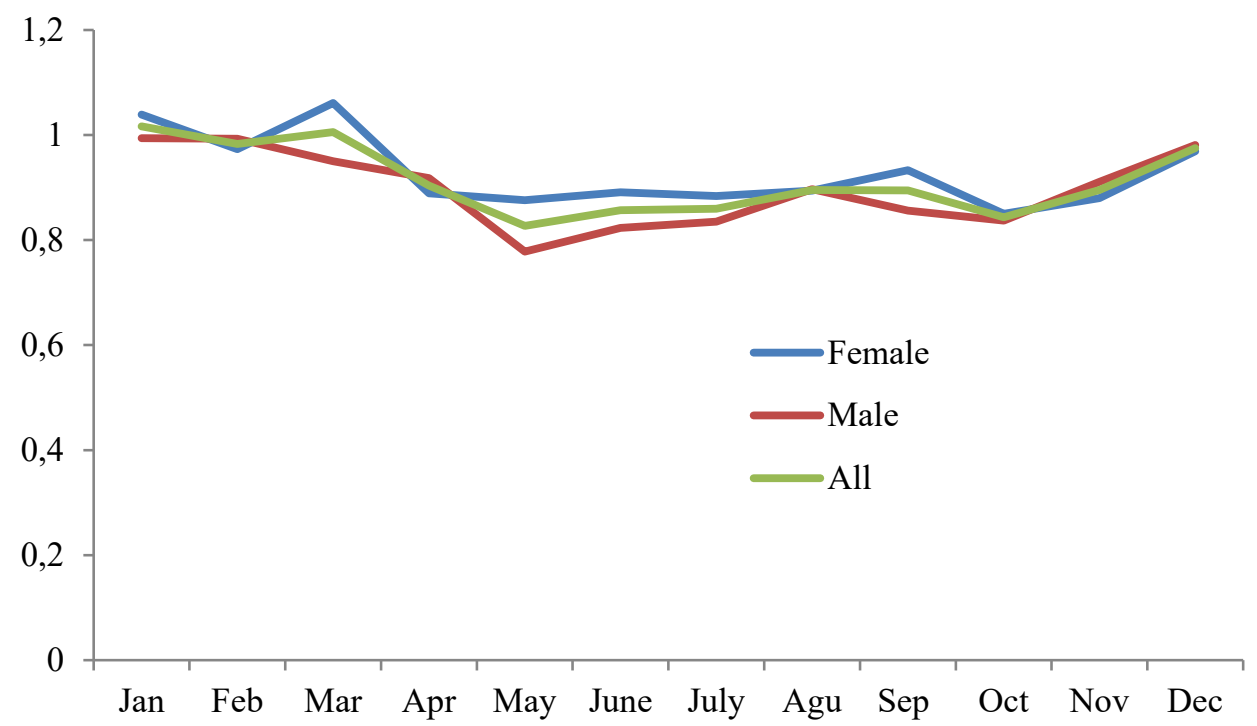

Figure 8. Monthly distribution of the Condition factor (CF) for Mesogobius batrachocephalus

Table 1. Total length and weight data of Mesogobius batrachocephalus for the total individuals and for separate sexes

\begin{tabular}{lcccccccccc}
\hline & \multicolumn{1}{c}{ Length (cm) } \\
\cline { 2 - 11 } & Mean & \pm & SD & Min. & Max. & Mean & \pm & SD & Min. & Max. \\
\hline All & 23.1 & \pm & 4.75 & 5.3 & 34 & 130.1 & \pm & 77.63 & 1.34 & 377.54 \\
Female & 22.9 & \pm & 4.56 & 5.3 & 34 & 128.9 & \pm & 75.00 & 1.34 & 372.90 \\
Male & 23.2 & \pm & 4.93 & 9.1 & 33.4 & 131.2 & \pm & 80.05 & 5.91 & 377.54 \\
\hline
\end{tabular}


Table 2. Total length and weight data of the Mesogobius batrachocephalus for different age groups

\begin{tabular}{cccccccc}
\hline Age & \multirow{2}{*}{$\mathbf{( N )}$} & \multicolumn{3}{c}{$\begin{array}{c}\text { L (cm) } \\
(\text { Mean } \pm \text { SD) }\end{array}$} & \multicolumn{3}{c}{$\begin{array}{c}\text { W (g) } \\
\text { (Mean } \pm \text { SD) }\end{array}$} \\
\hline 0 & 19 & 13.96 & \pm & 2.63 & 26.29 & \pm & 9.51 \\
1 & 250 & 19.16 & \pm & 2.32 & 66.18 & \pm & 28.94 \\
2 & 142 & 23.15 & \pm & 2.41 & 122.40 & \pm & 38.23 \\
3 & 146 & 27.44 & \pm & 1.96 & 201.49 & \pm & 50.80 \\
4 & 56 & 28.36 & \pm & 1.19 & 216.81 & \pm & 40.99 \\
5 & 22 & 30.49 & \pm & 0.95 & 257.08 & \pm & 47.24 \\
6 & 5 & 32.36 & \pm & 0.69 & 297.44 & \pm & 54.78 \\
7 & 1 & 34.00 & \pm & 0.00 & 272.78 & \pm & 0.00 \\
\hline Total & $\mathbf{6 4 1}$ & & & & & & \\
\hline
\end{tabular}

Table 3 Von Bertalanffy growth parameters and growth equations in Mesogobius batrachocephalus

\begin{tabular}{|c|c|c|c|c|c|c|}
\hline \multicolumn{5}{|c|}{ Growth parameters } & Length-growth functions & $\begin{array}{c}\text { Weight-growth } \\
\text { functions }\end{array}$ \\
\hline $\mathbf{L}_{\infty}$ & $\mathbf{W}_{\infty}$ & $\mathbf{K}$ & $\mathbf{t}_{\mathbf{0}}$ & $\mathbf{b}$ & $L(t)=L_{\infty}\left(1-e^{-k(t-t o)}\right)$ & $W(t)=W_{\infty}\left(1-e^{-k(t-t o)}\right)^{b}$ \\
\hline 38.2 & 432.34 & 0.2450 & -1.873 & 3.148 & $\mathrm{~L}(\mathrm{t})=38.2\left(1-\mathrm{e}^{-0.2450(\mathrm{t}}\right.$ & $\mathrm{W}(\mathrm{t})=432.34\left(1-\mathrm{e}^{-0.245}\right.$ \\
\hline
\end{tabular}

Table 4 The morphometric characteristics of Mesogobius batrachocephalus

\begin{tabular}{lccccc}
\hline Characters & Mean & SE & Min. & Max. & TL\% \\
\hline Total length (cm) & 23.5 & 5.47 & 9.1 & 33.4 & 100 \\
Standard length (cm) & 20.07 & 4.66 & 8.2 & 28.4 & 85.4 \\
Head length (cm) & 5.77 & 1.35 & 2.6 & 8.4 & 24.6 \\
Post-orbital distance (cm) & 3.04 & 0.74 & 1.3 & 4.4 & 12.9 \\
Eye diameter (cm) & 0.87 & 0.19 & 0.5 & 1.3 & 3.7 \\
Pre-dorsal distance (cm) & 6.87 & 1.60 & 3.0 & 10.6 & 29.2 \\
Length of D1 fin basis (cm) & 2.96 & 0.81 & 1.1 & 4.4 & 12.6 \\
Length of D2 fin basis (cm) & 6.66 & 1.59 & 2.7 & 9.6 & 28.3 \\
Pre-anal distance (cm) & 11.94 & 3.02 & 4.8 & 17.4 & 50.8 \\
Length of anal fin basis (cm) & 5.05 & 1.10 & 2.1 & 7.4 & 21.5 \\
Max. body depth (cm) & 3.02 & 0.78 & 1.0 & 5.3 & 12.9 \\
Caudal peduncle minimal depth (cm) & 1.31 & 0.33 & 0.5 & 1.9 & 5.6 \\
Pectoral length (cm) & 3.66 & 0.88 & 1.6 & 5.8 & 15.6 \\
Pelvic length (cm) & 2.49 & 0.52 & 1.4 & 3.6 & 10.6 \\
Total weight (g) & 127.78 & 81.50 & 5.9 & 337.8 & -- \\
\hline
\end{tabular}

TL: Total length, SE: Standard Error, Min: Minimum, Max: Maximum 
Table 5. Regression relationships and formulas in morphometric characters

\begin{tabular}{lc}
\hline Regression formula & $\mathbf{r}^{2}$ \\
\hline $\mathrm{SL}=0.8485 \mathrm{TL}+0.1307$ & 0.994 \\
$\mathrm{HL}=0.2459 \mathrm{TL}-0.0143$ & 0.988 \\
$\mathrm{POD}=0.1324 \mathrm{TL}-0.0759$ & 0.973 \\
$\mathrm{ED}=0.0324 \mathrm{TL}+0.1087$ & 0.880 \\
$\mathrm{PDD}=0.2901 \mathrm{TL}+0.056$ & 0.984 \\
$\mathrm{D} 1 \mathrm{~L}=0.1448 \mathrm{TL}-0.440$ & 0.968 \\
$\mathrm{D} 2 \mathrm{~L}=0.2873 \mathrm{TL}-0.0889$ & 0.983 \\
$\mathrm{PAD}=0.5473 \mathrm{TL}-0.9196$ & 0.985 \\
$\mathrm{AL}=0.1982 \mathrm{TL}+0.3902$ & 0.979 \\
$\mathrm{MBD}=0.1384 \mathrm{TL}-0.2305$ & 0.941 \\
$\mathrm{CPMD}=0.0583 \mathrm{TL}-0.0636$ & 0.941 \\
$\mathrm{PecL}=0.1578 \mathrm{TL}-0.0514$ & 0.961 \\
$\mathrm{PelL}=0.0919 \mathrm{TL}+0.3338$ & 0.936
\end{tabular}

Total length: TL, Standard length: SL, Head length: HL, Post-orbital distance: POD, Eye diameter: ED, Pre-dorsal distance: PDD, Length of D1 fin basis: D1L, Length of D2 fin basis: D2L, Pre-anal distance: PAD, Length of anal fin basis: AL, Max. body depth: MBD, Caudal peduncle minimal depth: CPMD, Pectoral length: PecL, Pelvic length: PelL

The closest relationship was found between the total length (TL) and standard length (SL) with a linear regression value of $r^{2}=0.99$ and the weakest relationship was found to be with $\mathrm{TL}$ and the eye diameter $\left(\mathrm{r}^{2}=0.88\right)$.

M. batrachocephalus is an endemic species of the Black Sea, the Sea of Azov and Caspian Sea. It lives in estuaries, brackish lagoons and occasionally in fresh waters (Freyhof, 2011; Froese and Pauly, 2019) and it has a certain commercial value (Patzner et al., 2011). In this study, all individuals were sampled between the depths of 2- $120 \mathrm{~m}$ in the Southern Black Sea coast. M. batrachocephalus was sampled $120 \mathrm{~m}$ depth. Although Miller (1986) reported that M. batrachocephalus is rarely found at a depth of $100 \mathrm{~m}$, some of the samples of this study was obtained from as deep as $120 \mathrm{~m}$. Keskin (2012) stated that the species exemplifies intensely at depths of 22$52 \mathrm{~m}$ in the south-western Black Sea shelf. Even though the species is endemic to the Black Sea, there are no studies focusing on the growth, population parameters, reproduction and its morphometric characters. The majority of studies are about the feeding habits limited to the region of the Romanian coastal of the Black Sea (Porumb, 1961; Bănărescu, 1964; Mihălcescu, 2005; Crețeanu and Papadopol, 2006; Roşca and Surugiu, 2010; Roșca and Mânzu, 2011). Only few works exist in the literature studying the length and weight relationship in Turkey coast with less number of individuals when compared with this study (Demirhan and Can, 2007; Ak et al., 2009; Çalık and Erdoğan-Sağlam, 2017).
A total of 641 individuals, 335 males and 306 females, of knout goby were sampled during this study. Length of the sampled individuals ranged from 5.3-34.0 cm and with a variation in weight from $1.34 \mathrm{~g}$ to $377.54 \mathrm{~g}$ (Table 1). A previous study conducted in the Black Sea is given Table 6 . It has been reported that this species can grow up to $20 \mathrm{~cm}$ length and $200 \mathrm{~g}$ weight in the Azov Sea (URL, 1). Patzner et al., (2011) indicated that the species may reach maximum of length of $35 \mathrm{~cm}$. In this study, a $34 \mathrm{~cm}$ length individual is sampled. M. batrachocephalus is larger than the all other goby species liv-ing in the Black Sea and the Azov Sea (Engin, 2008, URL, 1).

Bengil and Aydin (2020) stated positive allometry growth for M. batrachocephalus but Demirhan and Can (2007), Ak et al., (2009), Çalık and Erdoğan-Sağlam (2017) reported that this species shows a negative allometry. However, in this study, growth was found to have positive allometry $(b>3)$ $(\mathrm{P}>0.05)$. In these three studies relatively smaller individuals (max: 23.5) were sampled, however $50.2 \%$ of the obtained individuals are larger than $23 \mathrm{~cm}$ in this study, thus resulting in a higher " $b$ " value as there are more mature individuals sampled.

The allometric coefficient (b) may differ between sexes and between juvenile and adult samples (Hartnoll, 1974).

The average egg diameter was calculated as $2733.0 \mu \mathrm{m}$ in this study. Egg diameter and fecundity data of Mesogobius genus could not be found in the literature. 
Table 6. Growth parameters of previous studies from the Black Sea

\begin{tabular}{lcccccc}
\hline References & $\mathbf{N}$ & Lmin-Lmax & $\mathbf{a}$ & $\mathbf{b}$ & $\boldsymbol{r}^{\mathbf{2}}$ & Region \\
\hline Demirhan and Can (2007) & 37 & $7.2-13.3$ & 0.0203 & 2.750 & 0.930 & Black Sea \\
Ak et al. (2009) & 184 & $5.5-18.0$ & 0.0240 & 2.736 & 0.913 & Black Sea \\
Çalık and Erdoğan-Sağlam (2017) & 35 & $12.2-23.5$ & 0.0149 & 2.776 & 0.920 & Black Sea \\
Roşca and Mânzu (2011) & 227 & $16.1-22.6$ & --- & --- & --- & Black Sea \\
Bengil and Aydın (2020) & 470 & $12.6-31.8$ & 0.0062 & 3.130 & 0.960 & Black Sea \\
This study & 641 & $5.3-34.0$ & 0.0058 & 3.148 & 0.962 & Black Sea \\
\hline
\end{tabular}

There had been published reports about egg diameters for another goby fish, Neogobius melanostomus, habiting in the Black Sea and has a smaller egg diameter than the knout goby (Engin, 2008; Lavrincikova and Kovac, 2007; Hôrková and Kovác ${ }^{2}$, 2014). In this study, average fecundity of Mesogobius batrachocephalus was calculated as 4253.6 (Min: 1707.7, Max: 9209.5). Engin (2008) reported average fecundity as 1325 eggs, Lavrincikova and Kovac (2007) 557 eggs, Hôrková and Kovác (2014) 3512 eggs for N. melanostomus.

The reproductive time of the knout goby is during the spring season (Bănărescu, 1964; Berg, 1965; Roşca and Mânzu, 2011). In this study, it was shown that the reproduction took place in March. Similarly, Engin (2008) reported a spawning period in March for Neogobius platyrostris, Gobius paganellus and Gobius cobitis in the Black Sea. Kottelat and Freyhof (2007) mentioned that the species can reach a maximum of age of 8 . However, in the present study, the maximum age was similarly found as 7 .

In this study; total mortality, natural mortality and fishing mortality rates were found as $0.481,0.466$ and 0.015 , respectively. These are first time results for M. batrachocephalus in the literature. The fact that the fishing mortality rate $(0.015)$ being close to zero indicates that there is no fishing pressure on this species (Simpfendorfer et al., 2005). Morphometric characteristics of this species were also first added to the literature by this study.

\section{Conclusion}

The species is one of the discard species catch of the coastal fisheries of the Black Sea and has become more abundant in the discard composition. Due to its large size, it has a certain commercial value in some regions and is popular for sport fishers (Patzner et al., 2011). It has also sold at fish markets. Thus, this species has become a potential commercially valuable fish for coastal fisheries on the Black Sea coast of Turkey. Aim of this study is to contribute to the limited knowledge of knout goby population parameters and its mor- phometry inhabiting Southern Black Sea. This is the first major population parameter information of $M$. batrachocephalus. Knowledge of this information has a great importance for fisheries managers, decision makers (General Directorate of fisheries) and marine scientists.

\section{Compliance with Ethical Standard}

Conflict of interests: The authors declare that for this article they have no actual, potential or perceived conflict of interests.

Ethics committee approval: Ethics committee approval is not required for this study.

Funding disclosure: This project was supported by Scientific Research Coordination Department of Ordu University with a code AP-1735.

\section{Acknowledgments: -}

Disclosure: -

\section{References}

Ak, O., Kutlu, S., Aydın, I. (2009). Length-weight relationship for 16 fish species from the Eastern Black Sea, Turkey. Turkish Journal of Fisheries and Aquatic Science, 9, 125-128.

Bănărescu, P. (1964). Fauna RPR. Pisces-Osteichthyes. Vol XVIII, Editura R.P.R., București.

Bengi l, E.G.T., Aydın, M. (2020). The length and weight re-lationships and feeding ecology of knout goby,

Mesogobius batrachocephalus (Pallas, 1814) from Southern Black Sea. Ege Journal of Fisheries and Aquatic Sciences, 37(4), 409-414.

https://doi.org/10.12714/egejfas.37.4.12

Berg, L.S. (1965). Freshwater fishes of the U.S.S.R. and adjacent countries. Volume 3, 4th edition. Israel Program for Scientific Translations Ltd, Jerusalem. 
Beverton, R.J.H., Holt, S.J. (1957). On the dynamics of exploited fish populations. Fisheries Investigations, 19, 1-533.

Çalık, S., Erdoğan Sağlam, N. (2017). Length-weight relationships of demersal fish species caught by bottom trawl from Eastern Black Sea (Turkey). Cahiers de Biologie Marine, 58, 485-490.

Crețeanu, M., Papadopol, M.C. (2006). Population structure, nutrition, reproduction of Mesogobius batrachocephalus (Pallas, 1811) (Pisces, Gobiidae) (Preliminary Data). Cercetari Marine, INCDM, Constanta, 36, 319-340.

De Vlaming, V., Grossman, G., Chapman, F. (1982). On the use of the gonadosomatic index. Comparative Biochemistry and Physiology Part A: Physiology, 73(1), 31-39.

https://doi.org/10.1016/0300-9629(82)90088-3

Demirhan, S.A., Can, M.F. (2007). Length-weight relationships for seven fish species from the southeastern Black Sea. Journal of Applied Ichthyology, 23(3), 282-283.

https://doi.org/10.1111/j.1439-0426.2007.00835.x

Engin, S. (2008). Bio-ecological characteristic of some gobies Neogobius platyrostris (Pallas, 1814), Neogobius melanostomus (Pallas, 1814), Gobius paganellus Linnaeus, 1758 and Gobius cobitis Pallas, 1814 in the south eastern Black Sea rocky shore coastal ecosystem. PhD Thesis, Trabzon, Turkey: Karadeniz Technical University, 198 pp.

Freyhof, J. (2011). Diversity and distribution of freshwater gobies from the Mediterranean, the Black and Caspian Seas. The Biology of Gobies. Science Publishers, Enfield, NH, 279-288.

https://doi.org/10.1201/b11397-19

Froese, R., Pauly, D. (2019). FishBase. Mesogobius batrachocephalus (Pallas, 1814). Accessed through: World Register of Marine Species at: http://www.marinespecies.org/aphia.php? $p=$ taxdetails\&id=126909 on 2019-02-15.

Gulland, J.A. (1969). Manual of methods for fish stock assessment. Part I. Fish population analysis. FAO Manuals in Fisheries Science, 4, 44.

Hartnoll, R.G. (1974). Variation in growth pattern between some secondary sexual characters in crabs (Decapoda, Brachyura). Crustaceana, 27,131-136.

https://doi.org/10.1163/156854074X00334

Holden, M.J., Raitt, D.F.S. (eds) (1974). Manual of fisheries science. Part 2: Methods of resource investigation and their application. FAO Fishery Technology Paper 115 (Rev. 1), Rome, Italy.

Hôrková, K., Kováč , V. (2014). Different life-histories of native and invasive Neogobius melanostomus and the possible role of phenotypic plasticity in the species' invasion success. Knowledge and Management of Aquatic Ecosystems, 412, 1-11.

https://doi.org/10.1051/kmae/2013081

Keskin, C. (2012). A preliminary study on demersal fishes in the south-western Black Sea shelf (NW Turkey). Journal of Black Sea/Mediterranean Environment, 18(3), 341-349.

King, M. (1995). Fisheries Biology, Assessment and Management, Osney Mead, Oxford OX2 OEL, England.

Kottelat, M., Freyhof, J. (2007). Handbook of European freshwater fishes. Publications Kottelat, Cornol and Freyhof, Berlin. 646 pp. ISBN: 9782839902984

Lavrincikova, M., Kováč̌, V. (2007). Invasive round goby Neogobius melanostomus from the Danube mature at small size. Journal of Applied Ichthyology, 23, 276-278. https://doi.org/10.1111/j.1439-0426.2007.00851.x

Lowerre-Barbieri, S.K., Brown-Peterson, N.J., Murua, H., Tomkiewicz, J., Wyanski, D.M., Saborido-Rey, F. (2011). Emerging issues and methodological advances in fisheries reproductive biology. Marine and Coastal Fisheries, 3(1), 32-51.

https://doi.org/10.1080/19425120.2011.555725

Mihălcescu, A.M. (2005). Studiul sitematic și ecologic al gobiidelor (Pisces, Gobiidae) din apele dobrogene. Teză de doctorat, Editura Universității Ovidius, Constanța.

Miller, P.J. (1986). Gobiidae. p. 1019-1085. In P.J.P. Whitehead, M.-L. Bauchot, J.-C. Hureau, J. Nielsen and E. Tortonese (eds.) Fishes of the North-eastern Atlantic and the Mediterranean. Volume 3. UNESCO, Paris.

Patzner, R.A., Van Tassell, J.L., Kovačić, M., Kapoor, B.G. (2011). The biology of gobies. Enfield, NH: Science Publishers; Boca Raton, FL: Distributed by CRC Press, 685 p. ISBN: 9781578084364

https://doi.org/10.1201/b11397

Pauly, D. (1980). On the interrelationships between natural mortality, growth parameters, and mean environmental temperature in 175 fish stocks. ICES Journal of Marine Science, 
39(2), 175-192.

https://doi.org/10.1093/icesjms/39.2.175

Pauly, D. (1984). Fish population dynamics in tropical water: a manual for use with programme calculators. ICLARM Studies and Reviews 8. 325 pp.

Pauly, D., Munro, J.L. (1984). Once more on the comparison of the growth in fish and invertebrates, ICLARM Fishbyte, 2(1), 21.

Pinchuk, V.I., Vasil'eva, E.D., Vasil'ev, V.P., Miller, J.P. (2004). Mesogobius batrachocephalus (Pallas, 1814). In: The Freshwater fishes of Europe Vol. 8/II - Gobiidae 2, Miller J. P. (ed), pp. 109-131, AULA-Verlag, Wiebelsheim. 478 pp. ISBN: 9783891046692

Porumb, I. (1961). Contribuții la cunoașterea biologiei guvizilor (Gobius batrachocephalus, Gobius cephalarges și Gobius melanostomus) din dreptul litoralului românesc al Mării Negre (date preliminare). Hidrobiologia, 3, 271-282.

Ricker, W.E. (1975). Computation and interpretation of biology statistics of fish populations. Bulletin of the Fisheries Research Board of Canada, 191, 382.
Roşca, I., Mânzu, C.C. (2011). Feeding ecology of knout goby (Mesogobius batrachocephalus Pallas, 1814) from the Romanian Black Sea (Agigea-Eforie Nord area). Aquaculture, Aquarium, Conservation and Legislation, 4(2), 123129.

Roşca, I., Surugiu, V. (2010). Feeding Ecology of Some Benthic Fish Species From the Romanian Black Sea Coast (Agigea-Eforie Nord Area). Analele tiin ifice ale Universităii LVI.

Simpfendorfer, C.A., Bonfil, R., Latour, R.J. (2005). Mortality estimation. FAO Fisheries Technical Paper, 474, 127.

Sparre, P., Venema, S.C. (1992). Introduction to Tropical Fish Stock Assessment. Part I. Manual. FAO Fisheries Technical Paper No.306, 376p. ISBN: 9251039968

URL, 1. http://ribalkainfo.ru/stati-o-rybalke/riba-nashihvodoemov/46-bychok-knut-martovik.html

Yankova, M.H., Pavlov, D., Ivanova, P., Karpova, E., Boltachev, A., Öztürk, B., Bat, L., Oral, M., Mgeladze,M. (2014). Marine fishes in the Black Sea: recent conservation status. Mediterranean Marine Science, 15(2), 366-379. https://doi.org/10.12681/mms.700 